\title{
INTERAKSI SIMBOLIK KARYAWAN HOMOSEKSUAL DI SURABAYA
}

\section{INTERACTION SYMBOLIC OF HOMOSEXUAL IN SURABAYA}

\author{
Edelweis Putri Prima1, Puspita Lestari ${ }^{2}$ \\ Program Studi Ilmu Komunikasi Stikosa - AWS \\ Email : edelweisputriprima@gmail.com
}

\begin{abstract}
The thesis entitled "Symbolic Interaction of Homosexual Employees in Surabaya", aims to find out the symbolic exchange in homosexual employees' interpersonal communication in Surabaya. In this thesis, homosexuality is understood as a subject that has a pattern or behavior of interpersonal communication that refers to a typical symbol. To uncover the problems raised in this thesis, researchers are based on qualitative research methods. The selection of the method was caused by the relevance of the method in uncovering research problems. This relevance can be seen in the ability of this method to uncover homosexual employees' interpersonal communication processes in Surabaya. As a sharpening analysis, this thesis underlies the understanding of Symbolic Interactionism Theory. Based on the analysis, the researchers found that there are several things in homosexual employees' communication behavior, namely: 1) the existence of taboo assumptions in the minds of homosexuals themselves, 2) the existence of closed and open symbolic games displayed by homosexual individuals in the social world, 3) not all homosexual individuals display symbols that refer to female behavior in communication activities.activities.
\end{abstract}

Keywords: symbolic interaction, interpersonal communication, homosexual employees

\begin{abstract}
ABSTRAK
Penelitian berjudul "Interaksi Simbolik Karyawan Homoseksual di Surabaya", ini bertujuan untuk mengetahui pertukaran simbolik dalam komunikasi interpersonal karyawan homoseksual di Surabaya. Dalam penelitian ini, homoseksual dipahami sebagai subjek yang memiliki pola atau perilaku komunikasi interpersonal yang merujuk pada simbol yang khas. Untuk mengungkap permasalahan yang dimunculkan dalam penelitian ini, peneliti berdasar pada metode penelitian kualitatif. Adapun pemilihan
\end{abstract}

ISSN 2338 - 0861 (cetak); e-ISSN 2621 - 8712 (online)

website $\quad:$ http://spektrum.stikosa-aws.ac.id 
metode terebut disebabkan oleh relevansi metode dalam mengungkap permasalahan penelitian. Relevansi tersebut tampak pada kemampuan metode ini dalam mengungkap proses komunikasi interpersonal karyawan homoseksual di Surabaya. Sebagai penajam analisis, skripsi ini melandasi pemahaman Teori Interaksionisme Simbolik. Berdasarkan analisis, peneliti menemukan bahwa dalam perilaku komunikasi karyawan homoseksual terdapat beberapa hal, yakni: 1) masih adanya anggapan tabu di dalam pikiran kaum homoseksual itu sendiri, 2) adanya permainan simbol yang tertutup dan terbuka yang diperlihatkan oleh individu homoseksual di dalam dunia sosial, 3) tidak semua individu homoseksual memperlihatkan simbolsimbol yang merujuk pada perilaku keperempuanan dalam kegiatan komunikasi.

Kata kunci: Interaksi Simbolik, Komunikasi Interpersonal, Karyawan Homoseksual

\section{PENDAHULUAN}

Manusia adalah mahluk sosial. Sebagai mahluk sosial, manusia memiliki kebutuhan untuk berinteraksi dengan manusia lainnya. Agar interaksi dapat terjadi manusia perlu untuk melakukan komunikasi. Komunikasi menjadi tindakan kunci manusia untuk memenuhi kodratnya sebagai mahluk sosial.

Komunikasi yang dilakukan oleh manusia sebagai sebuah pribadi disebut komunikasi interpersonal. Komunikasi interpersonal (interpersonal communication) adalah komunikasi yang dilakukan secara langsung antara seseorang dengan orang lain, antara dua orang atau lebih. Dalam tingkatan komunikasi ini, manusia sebagai pribadi melakukan tindakan penyesuaian diri dengan orang lain lewat peran pengirim dan penerima pesan.
Penelitian ini memfokuskan kajiannya pada pola interaksi simbolik yang terjadi pada praktik komunikasi interpersonal karyawan yang memiliki orientasi seksual homoseksual di Surabaya. Adapun dipilihnya fokus kajian ini disebabkan oleh tiga faktor. Pertama, keberadaan Surabaya sebagai kota besar di Indonesia. Sebagai salah satu kota terbesar di Indonesia, setelah Jakarta, Surabaya memiliki persamalahan sosial yang kompleks. Komplesitas tersebut disebabkan oleh keberagaman latar sosial, budaya, ekonomi, bahkan orientasi seksual yang terdapat di Surabaya.

Sebagai salah satu kota besar, Surabaya menjadi kota tujuan para pendatang untuk bekerja, menempuh pendidikan, dan sebagainya. Hal tersebut membuat Surabaya menjadi kota yang padat penduduk. Kepadatan penduduk tidak hanya berasal dari penduduk

ISSN 2338 - 0861 (cetak); e-ISSN 2621 - 8712 (online)

website : http://spektrum.stikosa-aws.ac.id 
asli, tetapi juga berasal dari penduduk pendatang. Berdasarkan hasil proyeksi penduduk yang dilakukan oleh Badan Pusat Statistik Surabaya pada tahun 2012, penduduk kota Surabaya diperkirakan mencapai 2,79 juta jiwa. Jumlah penduduk tersebut terdiri dari 49,33 persen penduduk laki-laki dan 50,67 persen penduduk perempuan.

Faktor kedua yang menjadi pertimbangan dipilihnya topik ini sebagai fokus kajian dalam penelitian adalah karyawan dalam melakukan interaksi simbolik dalam praktik komunikasi interpersonal. Lingkungan fisik karyawan di Surabaya merupakan yang khas yang dimiliki oleh karyawan tersebut. Lingkungan kerja karyawan Surabaya, tentunya, berbeda dengan lingkungan kerja karyawan di kota selain Surabaya dalam melakukan interaksi simbolik. Oleh karena itu, kekhasan ini perlu dipahami dan diungkap keberadaannya.

Faktor ketiga adalah faktor Homoseksual. Menurut Soejono (1998) homoseksual merupakan salah satu jenis dari orientasi seksual yang menempatkan laki-laki penyuka sesame jenis. Di Indonesia, orientasi ini merupakan orientasi seksual yang ditabukan. Hal ini tampak pada penerbitan Undang-Undang Nomor 18 Tahun 2014 tentang kesehatan jiwa. Di dalam undang-undang tersebut individu atau pribadi yang memiliki orientasi seksual homoseksual dianggap sebagai orang yang mengalami orang dengan masalah kejiwaan. Ini berarti bahwa homoseksual dianggap sebagai orang yang sakit jiwa. Ini menempatkan pribadi yang berorientasi seksual tersebut berusaha menutupi dirinya dari orang lain. Tentunya, usaha menutupi diri tersebut meciptakan pola komunikasi interpersonal yang berbeda dengan orang-orang yang dianggap "normal". Ini merupakan hal yang menarik untuk dikaji secara mendalam. Berdasarkan pemaparan tersebut, dapat dipahami, bahwa topik interaksi simbolik pada praktik komunikasi interpersonal karyawan homoseksual di Surabaya, menjadi hal yang pantas dan menarik untuk diteliti. Berdasarkan pemahaman ini, maka judul penelitian ini adalah "Interaksi Simbolik Karyawan Homoseksual di Surabaya".

Permasalahan yang dihadirkan dalam penelitian ini sebagai berikut: "Bagaimana interaksi simbolik karyawan homoseksual di Surabaya?"

\section{METODE PENELITIAN}

Penelitian ini merupakan penelitian kualitatif. Menurut Moleong, penelitian kualitatif adalah prosedur penelitian yang

ISSN 2338 - 0861 (cetak); e-ISSN 2621 - 8712 (online)

website : http://spektrum.stikosa-aws.ac.id 
menghasilkan data deskriptif berupa kata-kata tertulis atau lisan dari orang-orang dan perilaku yang diamati. Dipilihnya jenis penelitian tersebut disebabkan tujuan dari penelitian ini adalah menjelaskan fenomena homoseksual secara mendalam. Sebagaimana yang dinyatakan oleh Kriyantono bahwa penelitian kualitatif merupakan penelitian yang berusaha untuk menjelaskan fenomena dengan sedalamdalamnya melalui pengumpulan data sedalam-dalamnya.

\section{HASIL DAN PEMBAHASAN}

\section{A. Hasil Wawancara Informan}

Untuk mendapatkan data mengenai perilaku karyawan homoseksual di Surabaya, peneliti menetapkan tiga informan. Adapun pemilihan ketiga informan tersebut didasarkan faktor relevansi yang dimiliki oleh ketiga informan tersebut dengan topik dan permasalahan yang diangkat dalam penelitian ini. Berdasarkan amatan dan pertimbangan, peneliti menetapkan tiga karyawan perusahaan swasta di Surabaya menjadi informan bagi penelitian ini. Ketiga informan tersebut adalah 1) GJ, 2) EAP, dan 3) BO.

a. Hasil Wawancara Peneliti dengan Informan 1

$\begin{array}{ll}\text { Nama } & : \text { GJ } \\ \text { Umur } & : 26 \text { Tahun } \\ \text { Pekerjaan } & \text { : Karyawan } \\ \text { Perusahaan } & \text { Swasta di } \\ \text { Surabaya } & \end{array}$

Tabel 1. Hasil Wawancara Peneliti dengan GJ

\begin{tabular}{|c|c|}
\hline Pertanyaan & Jawaban \\
\hline $\begin{array}{l}\text { Apakah Anda } \\
\text { Homoseksual? }\end{array}$ & Iya \\
\hline $\begin{array}{lr}\text { Sudah } & \text { berapa } \\
\text { lamakah Anda } \\
\text { menjadi } \\
\text { Homoseksual? }\end{array}$ & $\begin{array}{l}\text { Hmmm... Aku } \\
\text { jadi } \\
\text { homoseksual } \\
\text { sudah lama. } \\
\text { Sekitar } \\
\text { sembilan } \\
\text { sampai } \\
\text { sepuluh } \\
\text { tahun. Tapi } \\
\text { mulai kecil } \\
\text { aku udah } \\
\text { tertarik } \\
\text { dengan } \\
\text { sesama jenis. } \\
\text { Cuma masih } \\
\text { malu-malu } \\
\text { gitu. Setelah } \\
\text { lulus SMA } \\
\text { aku mulai } \\
\text { berani } \\
\text { memperlihat } \\
\text { kan orientasi } \\
\text { homoseksual. } \\
\text { Mungkin } \\
\text { karena udah } \\
\text { gak kuat } \\
\text { ngempet aja. } \\
\text { Hahaha. }\end{array}$ \\
\hline $\begin{array}{l}\text { Apakah yang } \\
\text { membuat Anda } \\
\text { menjadi } \\
\text { Homoseksual? }\end{array}$ & $\begin{array}{l}\text { Ya, apa } \\
\text { ya...hmmm. } \\
\text { Kayaknya sih } \\
\text { ya mulai } \\
\text { lahir. Tapi } \\
\text { waktu kuliah } \\
\text { itu aku mulai } \\
\text { memperlihat } \\
\text { kan kalo aku } \\
\text { gay. }\end{array}$ \\
\hline $\begin{array}{l}\text { Apakah teman- } \\
\text { teman Anda di } \\
\text { kantor } \\
\text { mengetahui } \\
\text { bahwa Anda }\end{array}$ & $\begin{array}{l}\text { Kayaknya sih } \\
\text { gak tahu. } \\
\text { Tapi gak } \\
\text { tahu lagi ya } \\
\text { kalo mereka }\end{array}$ \\
\hline
\end{tabular}

ISSN 2338 - 0861 (cetak); e-ISSN 2621 - 8712 (online)

website $:$ http://spektrum.stikosa-aws.ac.id 


\begin{tabular}{|c|c|}
\hline Homoseksual? & $\begin{array}{l}\text { tahu. EGPlah, } \\
\text { Cint. Yang } \\
\text { penting ya } \\
\text { gini ini aku. }\end{array}$ \\
\hline $\begin{array}{l}\text { Bagaimanakah } \\
\text { penerimaan } \\
\text { teman-teman di } \\
\text { kantor Anda } \\
\text { ketika } \\
\text { mengetahui } \\
\text { bahwa Anda } \\
\text { Homoseksual? }\end{array}$ & $\begin{array}{l}\text { Kalo } \\
\text { sekarang sih } \\
\text { ya fine-fine } \\
\text { aja. Tapi } \\
\text { yang jelas I } \\
\text { don't care. } \\
\text { Biarin } \\
\text { mereka mau } \\
\text { bilang apa. } \\
\text { Kan aku } \\
\text { senior } \\
\text { mereka, jadi } \\
\text { mereka gak } \\
\text { berani bilang } \\
\text { macem- } \\
\text { macem ma } \\
\text { aku. Ini } \\
\text { untungnya } \\
\text { jadi senior. } \\
\text { Hahaha .... }\end{array}$ \\
\hline $\begin{array}{l}\text { Mengapa Anda } \\
\text { berperilaku } \\
\text { seperti } \\
\text { perempuan? } \\
\text { Maksudnya, } \\
\text { mengapa jika } \\
\text { Anda berbicara } \\
\text { atau bergerak } \\
\text { kok selemah- } \\
\text { lembut } \\
\text { perempuan? }\end{array}$ & $\begin{array}{l}\text { Ya, gak tahu } \\
\text { juga. Emang } \\
\text { udah dari } \\
\text { sananya. Gak } \\
\text { ada yang } \\
\text { dibuat-buat } \\
\text { kok, Cint. Ya } \\
\text { gini ini aku. } \\
\text { Memang } \\
\text { lembut } \\
\text { perasaanku. } \\
\text { Makanya } \\
\text { pacarku } \\
\text { suka. }\end{array}$ \\
\hline $\begin{array}{l}\text { Apakah seorang } \\
\text { Homoseksual } \\
\text { harus bergaya } \\
\text { keperempuanan } \\
\text { seperti Anda? }\end{array}$ & $\begin{array}{lr}\text { Ya, aku } & \text { kan } \\
\text { bottom. } & \text { Kalo } \\
\text { top } & \text { ya } \\
\text { gaklah. } & \text { Aku } \\
\text { kan yang } & \text { harus } \\
\text { disayang. }\end{array}$ \\
\hline Apakah & Top itu yang \\
\hline
\end{tabular}

\begin{tabular}{|c|c|}
\hline $\begin{array}{l}\text { perbedaan Top } \\
\text { dengan Bottom? }\end{array}$ & $\begin{array}{l}\text { jadi } \\
\text { cowoknya. } \\
\text { Kalo Bottom } \\
\text { itu yang jadi } \\
\text { ceweknya. } \\
\text { Kalo top itu } \\
\text { tampilannya } \\
\text { laki banget. } \\
\text { Kalo bottom } \\
\text { itu cewek } \\
\text { banget. } \\
\text { Biasanya } \\
\text { centil-centil } \\
\text { gitu. }\end{array}$ \\
\hline $\begin{array}{l}\text { Apakah Anda } \\
\text { tidak risih } \\
\text { berperilaku } \\
\text { seperti } \\
\text { perempuan? }\end{array}$ & $\begin{array}{l}\text { Gaklah. } \\
\text { Karena ya } \\
\text { memang } \\
\text { begini saya. } \\
\text { Mau gimana } \\
\text { lagi. Aku } \\
\text { memang } \\
\text { lemah- } \\
\text { lembut } \\
\text { orangnya. }\end{array}$ \\
\hline $\begin{array}{l}\text { Apakah Anda } \\
\text { punya pacar? }\end{array}$ & 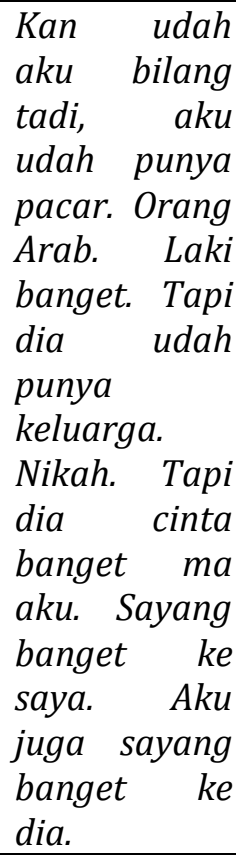 \\
\hline $\begin{array}{l}\text { Apakah Anda } \\
\text { senang jadi } \\
\text { Homoseksual? }\end{array}$ & $\begin{array}{lr}\text { Ya } & \text { gimana } \\
\text { ya, } & \text { Cint. Aku } \\
\text { sih } & \text { enjoy- }\end{array}$ \\
\hline
\end{tabular}

ISSN 2338 - 0861 (cetak); e-ISSN 2621 - 8712 (online)

website $:$ http://spektrum.stikosa-aws.ac.id 
enjoy aja.

Berdasarkan tabel 1 diatas tampak bahwa GJ merupakan karyawan sebuah perusahaan swasta di Surabaya yang memiliki orientasi seksual Homoseksual. Orientasi seksual tersebut telah dimilikinya sejak lama. Menurut penuturan GJ, orientasi seksual yang bersifat Homoseksual telah dimilikinya sejak kecil. Namun, orientasi seksual tersebut baru berani ditampakkannya ke masyarakat baru setelah lulus dari sekolah menengah atas.

Perilaku keseharian GJ di lingkungan kerja di Surabaya juga tetap memperlihatkan kecenderungan homoseksual yang dimilikinya. Bagi GJ, sebagaimana yang tampak pada tabel 1 diatas hal tersebut merupakan identitas yang dimilikinya. GJ beranggapan bahwa homoseksual merupakan kodrat bagi dirinya. Ini disebakan oleh kepercayaan GJ bahwa watak keperempuanan adalah bawaan lahir yang dimilikinya. Oleh karena itu, GJ berpendapat perilaku keperempuanan yang dia miliki tidak perlu ditutupi dari masyarakat. Hal tersebut semata karena dia memang menyadari bahwa dirinya adalah seorang Homoseksual. Hal tersebut tampak pada pernyataannya berikut:

"Gaklah. Karena ya memangb begini saya. Mau gimana lagi. Aku memang lemah-lembut orangnya."

Pernyataan

GJ tersebut memperlihatkan bahwa dia memiliki kesadaran mengenai kondisinya yang Homoseksual. Ini berdampak pada perilaku keseharian yang diperlihatkan. Dalam keseharian, perilaku yang mirip perempuan diperlihatkan oleh GJ secara terbuka.
Dia tidak menutupi atau menyembunyikan kondisi dirinya yang memang memiliki keberbedaan dengan laki-laki pada umumnya. Bahkan GJ dengan memiliki kebanggaan bahwa dirinya adalah homoseksual. Ini diperlihatkannya dengan tidak malu menyatakan bahwa dia memiliki pacar seorang laki-laki.

\section{b. Hasil Wawancara Peneliti dengan Informan 2 \\ Nama : EAP \\ Umur : 23 Tahun \\ Pekerjaan :Karyawan Perusahaan Swasta di Surabaya}

Tabel 2 Hasil Wawancara Peneliti dengan EAP

\begin{tabular}{|c|c|}
\hline Pertanyaan & Jawaban \\
\hline $\begin{array}{l}\text { Apakah Anda } \\
\text { Homoseksual? }\end{array}$ & $\begin{array}{l}\text { Iya. Tapi, diem- } \\
\text { diem aja ya, } \\
\text { Kakak. Tar gak } \\
\text { enak kalo orang } \\
\text { tau. }\end{array}$ \\
\hline $\begin{array}{l}\text { Sudah berapa } \\
\text { lamakah Anda } \\
\text { menjadi } \\
\text { Homoseksual? }\end{array}$ & $\begin{array}{l}\text { Kalo ngerasanya } \\
\text { sih udah lama. } \\
\text { Tapi ya baru 3-4 } \\
\text { tahun inilah aku } \\
\text { berani } \\
\text { membuka diri } \\
\text { kalo aku } \\
\text { homoseksual. } \\
\text { Tapi itu juga ke } \\
\text { aku sendiri. Ke } \\
\text { orang lain yang } \\
\text { belum terbuka } \\
\text { sepenuhnya. } \\
\text { Masih ke orang- } \\
\text { orang tertentu } \\
\text { aja. }\end{array}$ \\
\hline $\begin{array}{l}\text { Apakah yang } \\
\text { membuat Anda } \\
\text { menjadi } \\
\text { Homoseksual? }\end{array}$ & $\begin{array}{lr}\text { Apa } & \text { ya... } \\
\text { hmmm... } & y a \\
\text { mungkin udah } \\
\text { ada bibitnya } \\
\text { mulai kecil. Tapi }\end{array}$ \\
\hline
\end{tabular}

ISSN 2338 - 0861 (cetak); e-ISSN 2621 - 8712 (online)

website : http://spektrum.stikosa-aws.ac.id 


\begin{tabular}{|c|c|}
\hline & $\begin{array}{l}\text { mungkin karena } \\
\text { temen-temen } \\
\text { aku ngedance } \\
\text { banyak yang } \\
\text { gitu, jadi aku } \\
\text { sekarang gak } \\
\text { malu kalo } \\
\text { emang } \\
\text { homoseksual. }\end{array}$ \\
\hline $\begin{array}{l}\text { Apakah teman- } \\
\text { teman Anda di } \\
\text { kantor } \\
\text { mengetahui } \\
\text { bahwa Anda } \\
\text { Homoseksual? }\end{array}$ & $\begin{array}{lr}\text { Ya semoga aja } \\
\text { gak tau. Kalo } \\
\text { pun tau ya } \\
\text { semoga aja gak } \\
\text { aneh-aneh ke } \\
\text { aku. }\end{array}$ \\
\hline $\begin{array}{l}\text { Bagaimanakah } \\
\text { penerimaan } \\
\text { teman-teman di } \\
\text { kantor Anda } \\
\text { ketika } \\
\text { mengetahui } \\
\text { bahwa Anda } \\
\text { Homoseksual? }\end{array}$ & $\begin{array}{lr}\text { Kalo menurut } \\
\text { aku sih ya biasa- } \\
\text { biasa aja. } \\
\text { Soalnya, kalo } \\
\text { nurut aku, } \\
\text { banyak lho } \\
\text { temen-temen } \\
\text { yang juga gay. }\end{array}$ \\
\hline $\begin{array}{l}\text { Mengapa Anda } \\
\text { berperilaku } \\
\text { seperti } \\
\text { perempuan? } \\
\text { Maksudnya, } \\
\text { mengapa jika } \\
\text { Anda berbicara } \\
\text { atau bergerak } \\
\text { kok selemah- } \\
\text { lembut } \\
\text { perempuan? }\end{array}$ & $\begin{array}{l}\text { Ya suka aja. Aku } \\
\text { suka barang- } \\
\text { barang yang } \\
\text { feminim. Enak } \\
\text { banget rasanya } \\
\text { kalo makek. Jadi, } \\
\text { ya mungkin } \\
\text { karena itu. } \\
\text { Karena jiwaku } \\
\text { perempuan, jadi } \\
\text { kelakukanku ya } \\
\text { kayak } \\
\text { perempuan. Ini } \\
\text { coba sepatuku, aku } \\
\text { pake high heels. } \\
\text { Aku juga pake } \\
\text { lipstick. Biar } \\
\text { merah-merah } \\
\text { gimana gitu. }\end{array}$ \\
\hline $\begin{array}{l}\text { Apakah sec } \\
\text { Homoseksu } \\
\text { harus bel }\end{array}$ & $\begin{array}{l}\text { Gak juga. Ada } \\
\text { juga } \\
\text { gayanya mang }\end{array}$ \\
\hline
\end{tabular}

\begin{tabular}{|c|c|}
\hline $\begin{array}{l}\text { keperempuanan } \\
\text { seperti Anda? }\end{array}$ & $\begin{array}{l}\text { banget. } \\
\text { banget. Kayik } \\
\text { kenalanku itu. } \\
\text { Badannya. } \\
\text { Hmm... tapi, } \\
\text { sstttt. Jangan } \\
\text { rame-rame ya. }\end{array}$ \\
\hline $\begin{array}{l}\text { Apakah Anda } \\
\text { tidak risih } \\
\text { berperilaku } \\
\text { seperti } \\
\text { perempuan? }\end{array}$ & $\begin{array}{l}\text { Mungkin karena } \\
\text { udah ada di jiwa } \\
\text { ma hatiku ya, } \\
\text { jadi aku sih gak } \\
\text { risih. Cuma kalo } \\
\text { di kantor ya aku } \\
\text { masih sembunyi- } \\
\text { sembunyi. Masih } \\
\text { ngerasa gak } \\
\text { enak diliat } \\
\text { orang gitu. } \\
\text { Belum siap. } \\
\text { Padahal batinku } \\
\text { menderita. } \\
\text { Hahaha. }\end{array}$ \\
\hline $\begin{array}{l}\text { Apakah Anda } \\
\text { punya pacar? }\end{array}$ & $\begin{array}{l}\text { Ada sih yang } \\
\text { deket. } \\
\text { Menurutku sih } \\
\text { dia ganteng, } \\
\text { sabar, dan asyik } \\
\text { deh pokoknya. } \\
\text { Cuma ini mash } \\
\text { rahasia. Hehehe. }\end{array}$ \\
\hline $\begin{array}{l}\text { Di dalam } \\
\text { komunitas gay } \\
\text { ada yang } \\
\text { disebut Top dan } \\
\text { Bottom. Apakah } \\
\text { itu? }\end{array}$ & $\begin{array}{l}\text { Top itu kalo } \\
\text { yang } \\
\text { lakinya. Kadi } \\
\text { bottom itu yang } \\
\text { jadi ceweknya. } \\
\text { Kalo yang top } \\
\text { pasti gayanya } \\
\text { laki banget. } \\
\text { Cowok banget. } \\
\text { Ehem ehem deh } \\
\text { litany. }\end{array}$ \\
\hline
\end{tabular}

Berdasarkan hasil wawancara pada tabel 2 tampak bahwa EAP merupakan karyawan perusahaan swasta di Surabaya

ISSN 2338 - 0861 (cetak); e-ISSN 2621 - 8712 (online)

website $:$ http://spektrum.stikosa-aws.ac.id 
yang berjenis kelamin laki-laki tetapi memiliki orientasi seksual homoseksual. Orientasi seksual tersebut dirasakannya telah muncul sejak lama. Namun, sampai saat ini, dia masih malu untuk memperlihatkannya secara terbuka. Meskipun demikian, hal tersebut tidak menghalanginya untuk memperlihatkan watak keperempuanan yang dia miliki.

Watak keperempuanan EAP disebabkan oleh jiwa keperempuanan yang dia miliki. Jiwa keperempuanan tersebut ditandai dengan kenyamanannya ketika menggunakan barangbarang atau benda-benda yang mereferensi pada kebiasaan perempuan, seperti lipstick, sepatu high heels, dan penggunaan lensa kontak berwarna merah muda. Hal tersebut dilakukan oleh EAP secara sadar. Ini tampak pada penuturannya dalam tabel 3 yang berisi pengakuannya tentang jiwa perempuan yang dia miliki. Bagi EAP, perilaku keperempuanan

diperlihatkannya merupakan hal alamiah.

Namun, menurut EAP, tidak semua homoseksual berperilaku perempuan. Ada juga yang memperlihatkan sifat kelakilakian. Ini dia temui pada seorang laki-laki yang dia kenal. Bagi EAP, laki-laki tersebut sangat memperlihatkan watak kelaki-lakian. Bahkan jauh dari sifat lembut atau perilaku lemah seorang perempuan.

\section{c. Hasil Wawancara Peneliti dengan Informan BO

$\begin{array}{ll}\text { Nama } & : \text { BO } \\ \text { Umur } & : 26 \text { Tahun } \\ \text { Jabatan } & : \text { Karyawan }\end{array}$

Tabel 3. Hasil Wawancara Peneliti dengan BO

\begin{tabular}{|c|c|}
\hline Pertanyaan & Jawaban \\
\hline $\begin{array}{l}\text { Apakah Anda } \\
\text { Homoseksual? }\end{array}$ & $\begin{array}{l}\text { lya. Tapi jangan } \\
\text { bilang-bilang ya. } \\
\text { Gak enak didenger } \\
\text { orang. }\end{array}$ \\
\hline $\begin{array}{l}\text { Sudah berapa } \\
\text { lamakah Anda } \\
\text { menjadi } \\
\text { Homoseksual? }\end{array}$ & $\begin{array}{l}\text { Kalo ngerasanya sih } \\
\text { udah lama. Sejak } \\
\text { kecil aku suka liat } \\
\text { laki-laki yang } \\
\text { cantik. Gemes } \\
\text { rasanya. Tapi ya } \\
\text { masih malu-malu } \\
\text { waktu itu. Baru } \\
\text { setelah SMA aku } \\
\text { makin terobsesi ma } \\
\text { laki-laki. Seneng aja } \\
\text { liat laki-laki yang } \\
\text { ganteng, bersih, dan } \\
\text { agakcentil. }\end{array}$ \\
\hline $\begin{array}{l}\text { Apakah yang } \\
\text { membuat Anda } \\
\text { menjadi } \\
\text { Homoseksual? }\end{array}$ & $\begin{array}{l}\text { Apa ya... hmmm... ya } \\
\text { mungkin udah ada } \\
\text { bibitnya mulai kecil. } \\
\text { Seneng aja liat laki- } \\
\text { laki yang ganteng, } \\
\text { bersih, dan agak } \\
\text { centil gitu. Gemes. }\end{array}$ \\
\hline $\begin{array}{l}\text { Apakah teman- } \\
\text { teman Anda di } \\
\text { kantor } \\
\text { mengetahui } \\
\text { bahwa Anda } \\
\text { Homoseksual? }\end{array}$ & $\begin{array}{l}\text { Selama ini sih } \\
\text { berusaha } \\
\text { tutupin. Tapi mang } \\
\text { ada beberapa yang } \\
\text { tahu. Itu yang } \\
\text { mereka juga sama } \\
\text { kayak aku. Seneng } \\
\text { cowok. }\end{array}$ \\
\hline $\begin{array}{l}\text { Bagaimanakah } \\
\text { penerimaan } \\
\text { teman-teman di } \\
\text { kantor Anda }\end{array}$ & $\begin{array}{l}\text { Wah itu gaktau aku. } \\
\text { Aku kan berusaha } \\
\text { menutupi. Tapi kalo } \\
\text { mereka yang tahu, }\end{array}$ \\
\hline
\end{tabular}

ISSN 2338 - 0861 (cetak); e-ISSN 2621 - 8712 (online)

website : http://spektrum.stikosa-aws.ac.id 


\begin{tabular}{|c|c|}
\hline $\begin{array}{l}\text { ketika } \\
\text { mengetahui } \\
\text { bahwa Anda } \\
\text { Homoseksual? }\end{array}$ & \begin{tabular}{lrr} 
kayak & \multicolumn{2}{c}{ beberapa } \\
temen disini yang \\
pernah jalan ma \\
aku, mereka sih \\
nerima.
\end{tabular} \\
\hline $\begin{array}{l}\text { Mengapa Anda } \\
\text { tidak } \\
\text { berperilaku } \\
\text { seperti } \\
\text { perempuan? } \\
\text { Maksudnya, } \\
\text { mengapa jika } \\
\text { Anda berbicara } \\
\text { atau bergerak } \\
\text { kok tidak } \\
\text { selemah-lembut } \\
\text { perempuan? }\end{array}$ & $\begin{array}{lrr}\text { Gaykan gak harus } \\
\text { kayak perempuan. } \\
\text { Apalagi aku ini top. } \\
\text { Bottom gak suka } \\
\text { cowok r yang } \\
\text { lembeng. }\end{array}$ \\
\hline $\begin{array}{l}\text { Apakah seorang } \\
\text { Homoseksual } \\
\text { harus bergaya } \\
\text { keperempuanan } \\
\text { seperti Anda? }\end{array}$ & $\begin{array}{l}\text { Gak juga. Kalo dia } \\
\text { top ya gak kayak } \\
\text { perempuan. }\end{array}$ \\
\hline Apakah Top itu? & $\begin{array}{l}\text { Top itu yang jadi } \\
\text { laki. Di dunia gay } \\
\text { ada yang jadi laki, } \\
\text { ada yang jadi } \\
\text { ceweknya. Meski } \\
\text { kami semua laki } \\
\text { bukan berarti kami } \\
\text { memiliki posisi dan } \\
\text { perilaku yang sama. } \\
\text { Top ma bottom itu } \\
\text { beda banget. }\end{array}$ \\
\hline $\begin{array}{l}\text { Bagaimana } \\
\text { Anda } \\
\text { membedakan } \\
\text { yang } \quad \text { Top } \\
\text { dengan yang } \\
\text { Bottom? }\end{array}$ & $\begin{array}{l}\text { Yang Top pasti } \\
\text { gayanya gak kayak } \\
\text { cewek. Kalo bottom } \\
\text { pasti gayanya cewek } \\
\text { banget. Yang pake } \\
\text { baju centil-centil, } \\
\text { pake asesoris cewek } \\
\text { Biasanya badanya } \\
\text { kurus-kurus gemes } \\
\text { gitu. }\end{array}$ \\
\hline $\begin{array}{lr}\text { Apakah } & \text { Anda } \\
\text { tidak } & \text { risih } \\
\text { melihat } & \text { teman }\end{array}$ & $\begin{array}{l}\text { Biasa aja. Aku sih, } \\
\text { sebenernya malah } \\
\text { suka. Liat cowok- }\end{array}$ \\
\hline
\end{tabular}

\begin{tabular}{|l|l|}
\hline $\begin{array}{l}\text { Anda } \\
\text { berperilaku } \\
\text { seperti } \\
\text { perempuan? }\end{array}$ & cowok centil. Gemes. \\
\hline $\begin{array}{l}\text { Apakah Anda } \\
\text { punya pacar? }\end{array}$ & $\begin{array}{l}\text { Ada sih yang deket. } \\
\text { Tapi bukan anak } \\
\text { sini. }\end{array}$ \\
\hline
\end{tabular}

Di dalam tabel 3 tampak bahwa BO merupakan seorang lakilaki yang memiliki orientasi seksual homoseksual. Hal itu telah dirasakannya sejak lama. Namun, tidak seperti dua informan yang sebelumnya, BO bukan tipe homoseksual yang berperilaku keperempuanan. Bagi BO, menjadi gay atau homoseksual tidak harus berperilaku perempuan. Bisa saja menjadi sosok laki-laki yang memperlihatkan sifat jantan laki-laki. Namun, untuk masalah kertertarikan itu merupakan hal yang berbeda.

Sebagaimana EAP, BO juga tidak berani memperlihatkan watak homoseksual yang dimilikinya kepada publik secara terbuka. Bagi BO, dia merasa belum siap. Oleh karena itu, dalam kesehariannya, BO tetap berperilaku sebagaimana lakilaki pada umumnya. Kecenderungan

ketertarikannya pada laki-laki dia sembunyikan. Ini tampak pada pernyataannya dalam wawancara yang tidak mengetahui bagaimana respon masyarakat tentang perilakunya yang homoseksual.

\section{B. Analisis Data}

Dalam melakukan analisis, peneliti berpijak pada

ISSN 2338 - 0861 (cetak); e-ISSN 2621 - 8712 (online)

website : http://spektrum.stikosa-aws.ac.id 
pemahaman teori interaksionisme simbolik. Dalam konsep interaksionisme simbolik individu itu dipahami bukanlah sebagai seseorang yang bersifat pasif, yang keseluruhan perilakunya ditentukan oleh kekuatankekuatan atau struktur-struktur lain yang ada di luar dirinya, melainkan bersifat aktif, reflektif dan kreatif, menampilkan perilaku yang rumit dan sulit diramalkan.

Dalam memaknai perilaku tersebut, peneliti berpijak pada pemahaman tentang esensi interaksi sosial yang terdapat dalam teori interaksionisme simbolik. Dalam teori tersebut interaksi simbolik didasarkan pada ide-ide tentang individu dan interaksinya dengan masyarakat. Esensi interaksi simbolik adalah suatu aktivitas yang merupakan ciri manusia, yakni komunikasi atau pertukaran simbol yang diberi makna. Perspektif interaksi simbolik berusaha memahami perilaku manusia dari sudut pandang subjek. Agar analisis dapat dilakukan, peneliti memusatkan perhatiannya pada faktor-faktor yang menjadi elemen dari teori interaksionisme simbolik, yakni diri, berpikir, interaksi sosial, dan dunia sosial.

Konsep diri, dalam peneliti ini, dipahami dengan merujuk pada perilaku dan penampilan yang diperlihatkan oleh subjek penelitian. Secara individu, subjek dalam penelitian ini memiliki keragaman ketika mendefinisikan dirinya sebagai homoseksual. Pada GJ, keberadaan dirinya sebagai homoseksual tidak mengalami pengingkaran. Hal tersebut tampak pada pernyataannya berikut:
"Hmmm... Aku jadi homoseksual sudah lama. Sekitar 9-10 tahun. Tapi mulai kecil aku udah tertarik dengan sesama jenis. Cuma masih malu-malu gitu. Setelah lulus SMA aku mulai berani memperlihatkan orientasi homoseksual. Mungkin karena udah gak kuat ngempet aja. Hahaha."

Dalam pernyataan tersebut, tampak bahwa GJ memiliki kesadaran sebagai seorang homoseksual. Pernyataan tersebut bermakna bahwa GJ telah menyadari bahwa dirinya adalah seorang homoseksual dan tidak mengingkarinya. Bahkan dia menganggap hal itu merupakan hal yang biasa. Oleh karena itu kesadaran tersebut tidak dia ingkari. Ini tampak pada pernyataan GJ berikut:

"EGPlah, Cint. Yang penting ya gini ini aku .... Kalo sekarang sih ya fine-fine aja. Tapi yang jelas I don't care. Biarin mereka mau bilang apa. Kan aku senior mereka, jadi mereka gak berani bilang macem-macem ma aku. Ini untungnya jadi senior. Hahaha .... Ya, gak tahu juga. Emang udah dari sananya. Gak ada yang dibuat-buat kok, Cint. Ya gini ini aku. Memang lembut perasaanku. Makanya pacarku suka."

Kesadaran sebagai seorang homoseksual tersebut semakin ditegaskan oleh GJ dengan perilaku keseharian yang cenderung bersifat perempuan. Seperti penggunaan bedak pada wajah. Bedak adalah simbol perempuan. Hal tersebut disebabkan bedak merupakan sesuatu yang maknanya merujuk pada kelembutan dan keindahan. Hal yang lembut dan indah adalah sesuatu yang identik dengan perempuan. Bagi seorang laki-laki penggunaan bedak merupakan hal yang lazim dilakukan. Hal tersebut karena

ISSN 2338 - 0861 (cetak); e-ISSN 2621 - 8712 (online)

website : http://spektrum.stikosa-aws.ac.id 
merepresentasikan konsep diri yang lembut. Ini berbeda dengan perempuan. Wajah yang bersih dan lembut menjadi penanda bahwa dirinya merupakan sosok yang lembut.

Ini berdampak pada cara berpikir dan cara berinteraksi GJ. Dengan cara berbicara yang lebih merepresentasikan sifat perempuan, interaksi sosial yang dibangun GJ lebih merujuk pada interaksi sosial yang memperlihatkan watak homoseksual yang terbuka. Penggunaan kata Cint dalam sapaan, misalnya, merupakan penanda adanya peran homoseksual yang dimainkan secara terbuka oleh GJ. Ini pada akhirnya mengonstruksikan bangunan dunia sosial yang menerima keberadaan homoseksual.

Dalam interaksi di lingkungan pekerjaan, GJ memperlihatkan gesture atau gerakan-gerakan tubuh yang menyimbolkan watak keperempuanan yang dimilikinya. Simbol yang memperlihatkan watak keperempuanan GJ diperlihatkan dengan gerakan tubuh yang lemah lembut, disertai gaya bicara yang sedikit centil. Gerakan tubuh yang menyerupai perempuan itu ditampakkan oleh GJ melalui gerak tubuhnya yang sedikit gemulai ketika berhadapan dengan konsumen. Gaya berjabat tangan yang lemah lembut merupakan simbol watak keperempuanan yang dimiliki oleh GJ. Begitu juga dengan gaya bicara yang sedikit centil, seperti penggunaan kata "beb", atau "cint" sebagai kata sapaan, membuat GJ tampak sebagai sosok lelaki yang berwatak perempuan.

Namun, gerakan dan gaya bicara tersebut tidak terlalu kuat menampakkan watak keperempuanan GJ dibandingkan apabila dia berinteraksi dengan orang-orang selain konsumen. Dalam interaksinya dengan orang-orang selain konsumen, GJ begitu terbuka akan sifat atau watak keperempuanan yang dimilikinya. Itu ditampakkan dengan gaya berjalan GJ yang selalu menggoyang pinggulnya apabila sedang berjalan dengan kekasihnya sekeluar dari kantor.

Selain itu, watak keperempuanan GJ juga ditampakkan pada cara berpakaian yang lebih memilih menggunakan warna cerah. Warna seperti kuning, hijau muda, atau warna-warna pastel lainnya merupakan warna pakaian yang sering digunakan GJ di luar seragam kantor. Hal tersebut tentunya merupakan simbol yang dibangun GJ ketika melakukan interaksi di ranah sosial. Ada upaya GJ untuk mengartikulasikan keberadaannya sebagai sosok yang memiliki watak keperempuanan yang kuat.

Watak keperempuanan GJ merupakan watak yang melekat. Sebagai bottom, GJ memiliki pemikiran bahwa dirinya merupakan sosok yang berjiwa perempuan. Jiwa tersebut melekat pada diri GJ sebab dia memposisikan dirinya di dalam dunia sosial kaum gay sebagai bottom. Sebagai bottom GJ memposisikan dirinya bukan sebagai laki-laki yang maskulin, tetapi sebagai perempuan yang terperangkap di dalam tubuh laki-laki. Hal tersebut sebagaimana yang dinyatakan oleh GJ:

"Top itu kalo yang jadi lakinya. Kalo bottom itu yang jadi ceweknya. Kalo yang top pasti gayanya laki banget. Cowok banget."

ISSN 2338 - 0861 (cetak); e-ISSN 2621 - 8712 (online)

website : http://spektrum.stikosa-aws.ac.id 
Hal yang sama juga diperlihatkan oleh EAP. Sebagai karyawan laki-laki, EAP tidak segan untuk menggunakan bedak, lipstick, dan lensa kontak berwarna merah muda dalam kesehariannya di kantor. Tentunya ini memiliki maksud tertentu. Adapun hal tersebut bertujuan tidak hanya untuk mengekspresikan dirinya sebagai sosok laki-laki yang bersifat perempuan. Namun juga untuk menyimbolkan keberadaannya sebagai homoseksual.

Ketertutupan EAP mengenai konsep dirinya sebagai homoseksual tampak pada perilaku homoseksualnya yang tidak terbuka. Dalam berinteraksi di kantor, EAP masih berusaha untuk memperlihatkan sosoknya sebagai laki-laki pada umumnya. Misalnya dalam berbicara. Namun, perannya tersebut sering kali terlepas ketika dia duduk. Ketika duduk tampak sekali feminimitas EAP. Ketika duduk dia selalu menyilangkan kakinya, persis gaya duduk seorang perempuan. Gaya duduk tersebut merupakan simbol yang memaknai diri dan cara berpikir EAP yang cenderung bersifat perempuan.

Hal yang serupa ditemui dilakukan EAP kepada konsumen. Perilaku EAP ketika berinteraksi dengan konsumen memperlihatkan simbol-simbol yang tidak bersifat keperempuanan. Interaksi dengan konsumen ditantandai oleh EAP dengan perilaku yang normal, seperti gaya bicara yang tidak genit. Ini memperlihatkan bahwa ada upaya untuk mengelabui dunia sosial. Maksudnya bahwa di dunia sosia ada ketidaksiapan EAP untuk mengartikulasikan bahwa dirinya seorang homoseksual. Ini berarti konsep diri EAP sebagai seorang homoseksual yang memiliki watak keperempuanan merupakan hal tabu untuk diperlihatkan di dunia sosial. Ini juga memperlihatkan bahwa dalam pemikiran EAP homoseksualitas adalah kecenderungan yang harus ditutupi di dunia sosial. Ini pada akhirnya membentuk dunia sosial yang berbeda. Artinya, perilaku EAP tersebut membentuk dunia sosial yang berisi permainan peran tertutup. Ini berbeda dengan GJ.

Meskipun demikian, EAP mengakui keberadaan sebagai seorang homoseksual kepada orangorang tertentu yang dianggap mampu menerimanya. Hal tersebut sebagaimana yang tampak pada pernyataan berikut:

"Kalo ngerasanya sih udah lama. Tapi ya baru 3-4 tahun inilah aku berani membuka diri kalo aku homoseksual. Tapi itu juga ke aku sendiri. Ke orang lain yang belum terbuka sepenuhnya. Masih ke orang-orang tertentu aja .... Mungkin karena udah ada di jiwa ma hatiku ya, jadi aku sih gak risih. Cuma kalo di kantor ya aku masih sembunyisembunyi. Masih ngerasa gak enak diliat orang gitu. Belum siap. Padahal batinku menderita. Hahaha."

Pernyataan EAP tersebut bermakna bahwa kesadaran diri sebagai homoseksual memang telah ada dalam diri EAP, tetapi hal tersebut tetap ditutupi. Ini tampak pada pernyataannya yang masih takut untuk memperlihatkan dirinya sebagai homoseksual secara terbuka. Ini berdampak pada pola interaksi sosial yang diciptakan oleh EAP. Pola interaksi sosial EAP hadir yang pola yang lebih dramatik. Artinya, interaksi sosial yang dibangun tidak dengan

ISSN 2338 - 0861 (cetak); e-ISSN 2621 - 8712 (online)

website : http://spektrum.stikosa-aws.ac.id 
keterbukaan, namun lebih pada permainan peran para aktor.

Ini berdampak pada dunia sosial yang dibangun oleh EAP. Dunia sosial yang dibangun EAP merupakan dunia sosial yang menyerupai panggung pertunjukan teater atau drama. Dunia sosial EAP merupakan dunia sosial yang penuh dengan permainan peran. Oleh karena itu, dunia sosial EAP bukanlah dunia sosial yang terbuka, yang hadir dalam konteks realitas yang jujur. Dunia sosial EAP merupakan dunia sosial yang rekaan. Dibangun dalam kesadaran ketakukan dari konsep diri dan cara berpikir yang dimiliki oleh EAP sebagai homoseksual. Dunia sosial EAP adalah dunia sosial pengingkaran atas konsep diri EAP sebagai homoseksual.

Hal yang sama dengan EAP juga tampak pada BO. Secara konsep diri, BO mengakui bahwa dirinya adalah seorang laki-laki yang memiliki orientasi homoseksual. Itu tampak pada pernyataan BO berikut:

"Kalo ngerasanya sih udah lama. Sejak kecil aku suka liat laki-laki yang cantik. Gemes rasanya. Tapi ya masih malu-malu waktu itu. Baru setelah SMA aku makin terobsesi ma laki-laki. Seneng aja liat laki-laki yang ganteng, bersih, dan agak centil."

Namun, hal tersebut menemukan pengingkarannya dalam pola interaksi sosial yang dilakukan oleh BO. Dalam interaksi sosial, BO, berusaha memainkan peran sebagai laki-laki yang heteroseksual. Pada interaksi sosial, BO merupakan aktor yang membangun peran perwatakan sebagai laki-laki pada umumnya.

Pembentukan citra laki-laki normal yang dilakukan oleh BO memperlihatkan bahwa terdapat pemahaman mengenai ketabuan homoseksual dalam pikiran BO. Hal ini mendorong Biltomi untuk memainkan peran tertutup ketika berada di dunia sosial. Ini juga memperlihatkan dan mengonstruksikan makna konsep diri bahwa homoseksual merupakan hal yang tabu untuk ditampilkan dalam funia sosial. Ini tentunya berdampak pada dunia sosial yang dibangun oleh BO.

Dalam interaksinya dengan teman sejawat di kantor ataupun dengan konsumen, BO juga memperlihatkan simbol-simbol kelaki-lakian. Simbol kelakian yang dibangun oleh BO ditampakkan melalui gaya bicara yang tidak memperlihat watak keperempuanan, serta nada bicara yang tidak centil. Gaya bicara yang lugas dengan nada bicara seperti lakilaki pada umumnya merupakan simbol dari sifat kelakian yang dimiliki BO. Hal tersebut memperlihatkan bahwa ada upaya untuk membangun simbol laki-laki heteroseksual dalam diri BO.

Sebagai seseorang yang berjenis kelamin laki-laki, BO menganggap bahwa simbol-simbol keperempuan adalah hal yang tabu untuk diperlihatkan di dunia sosial. Penggunaan baju berkerah yang tidak terlalu berwarna lembut merupakan pilihan yang dilakukan BO untuk mengomunikasikan diri kepada dunia sosial sebagai laki-laki.

Dalam dunia sosial masyarakat Surabaya, laki-laki masih menjadi subjek yang dominan. Simbol keperkasaan dan kekuasaan adalah hal yang melekat pada laki-laki Surabaya. Ini juga yang membuat BO berusahaa untuk memperlihatkan sifat kelaki-lakian yang penuh kepercayaan dan kekuatan.

ISSN 2338 - 0861 (cetak); e-ISSN 2621 - 8712 (online)

website : http://spektrum.stikosa-aws.ac.id 
Dunia sosial yang dibangun BO adalah dunia sosial yang menempatkan perilaku homoseksual sebagai sesuatu yang tabu. Peran laki-laki heteroseksual yang dimainkan oleh BO sebagai aktornya, memberikan pemahaman tentang adanya simbol bahwa laki-laki haruslah memiliki sifat jantan dan tidak boleh menyukai sesama jenis. Tentunya ini berdampak pada cara berpikir BO yang menempatkan homoseksual sebagai sesuatu yang tidak lazim untuk ditampilkan dalam dunia sosial Surabaya. Oleh karena itu, dunia sosial BO merupakan dunia sosial sebagaimana dunia sosial EAP: sebuah dunia sosial yang mirip pertunjukan drama.

\section{KESIMPULAN}

Berdasarkan analisis yang dilakukan, peneliti menyimpulkan bahwa interaksionisme simbolik dapat digunakan sebagai landasan teoritis dalam menganalisis pembentukan dunia sosial yang terjadi di masyarakat. Hal tersebut dilakukan dengan cara melihat bagaimana perilaku individu di dalam dunia sosial. Terdapat permainan simbol yang berbeda di dalam interaksi sosial yang dibangun oleh masyarakat homoseksual. Berdasarkan analisis ditemukan bahwa terdapat permainan tertutup dan terbuka oleh masyarakat homoseksual di dunia sosial. Tidak semua anggota masyarakat homoseksual mengomunikasikan simbol-simbol secara terbuka di dunia sosial. Pada Informan 2 dan Informan 3 simbol-simbol homoseksual dimainkan secara tertutup. Ini memperlihatkan adanya konsep diri dan pikiran yang masih memandang bahwa homoseksualitas merupakan hal yang tabu di masyarakat. Hal tersebut sediki berbeda pada Informan 1. Pada Informan 1 permainan simbol homoseksualitas sedikit terbuka. Namun, masih ada perilaku yang sedikit tertutup ketika berada di dunia sosial. Ini memperlihatkan bahwa konsep diri homoseksualitas dalam pemahaman Jalu juga masih dipandang sebagai sesuatu yang tabu di dunia sosial. Homoseksualitas masih merupakan hal yang tabu di dalam kehidupan masyarakat. Hal ini tampak pada usaha pembentukan dunia sosial masyarakat homoseksual yang masih belum terbuka. Memang telah ada upaya untuk membuka kemungkinan penerimaan terhadap individu yang memiliki kecenderungan homoseksual. Namun, hal tersebut belum benar-benar dilakukan secara terbuka. Ini tampak pada masih terbentuknya dunia sosial yang mirip permainan drama di dalam dunia sosial.

\section{DAFTAR PUSTAKA}

Buku

Agustina, Herdianti. 2006. Psikologi Perkembangan: Pendekatan Ekologi Kaitannya dengan Konsep Diri dan Penyesuaian Diri pada Remaja. Bandung: Refika Aditama.

Budyatna, Muhammad, 2011. Teori Komunikasi Antarpribadi. Jakarta: Kencana.

Cangara, Hafied. 2012. Pengantar Ilmu Komunikasi. Jakarta: Raja Grafindo Persada.

Hikmat, Mahi M.. 2011. Metode Penelitian dalam Perspektif Ilmu Komunikasi dan Sastra. Jogjakarta: Grahallmu.

ISSN 2338 - 0861 (cetak); e-ISSN 2621 - 8712 (online)

website : http://spektrum.stikosa-aws.ac.id 
Irawan, Prasetya. 2004. Logika dan ProsedurPenelitian. Jakarta: STIALAN Press.

Kriyantono, Rachmat. 2010. Teknik Praktis Riset Komunikasi. Jakarta: Kencana.

Liliweri, Alo. 1994. Perspektif Teoritis, Komunikasi Antarpribadi: Suatu Pendekatan Kearah Psikologi Sosial Komunikasi. Bandung : Citra Adhitya Bakti.

Littlejohn, Stephen W \& Karen A. Foss.2009. Teori Komunikasi, Edisi 9. Jakarta: Salemba Humanika

Lunandi, A.G.. 1994. Komunikasi Mengenai : Meningkatkan Efektivitas Komunikasi Antarpribadi. Yogyakarta : Kanisius.

Maryaeni. 2005. Metode Penelitian Kebudayaan. Jakarta: Bumi Aksara.

Marzuki. 2002. Metodologi Riset. Yogyakarta : Prasetya Widi Pratama.

Moleong, Lexy J. 2000. Metodologi Penelitian Kualitatif. Bandung: Remaja Rosdakarya.

Mulyana, Deddy. 2008. Ilmu Komunikasi Suatu Pengantar. Bandung: Remaja Rosdakarya.

Soedarjadi. 2008. Pengantar Hukum Ketenagakerjaan di Indonesia. Jakarta : Pustaka Yustisia.

Soehartono, Irawan. 2008. Metode Penelitian Sosial. Bandung: Remaja Rosdakarya.

Uchjana, Onong. 2004. Dinamika Komunikasi. Bandung: Remaja Rosdakarya.

\section{Artikel dari website dengan nama penulis}

\author{
Soejono. (2018, March 30). \\ "PatologiSosial". Diakses dari \\ http://tugas-patologi-dan- \\ masalahsosial,html.
}

Surabaya.Go.Id. (2018, August 20). "The History of Surabaya". Diakses dari

https://sparkling.surabaya.go.id/ about-surabaya/the-history-of-

surabaya/.

(2018, August 20). "Profil

Kota Surabaya". Diakses dari http://surabaya.go.id/berita/176 83-profil-kota-surabaya.

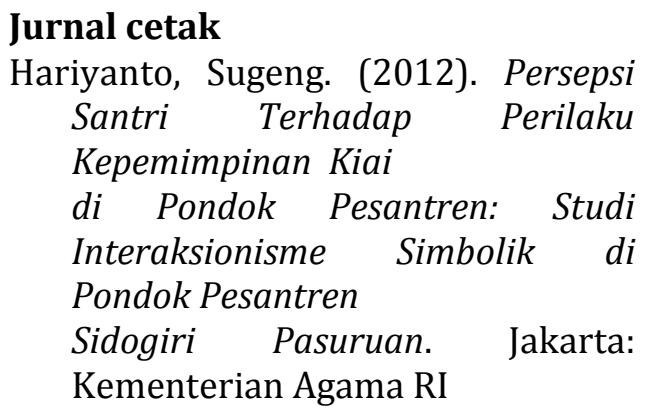

ISSN 2338 - 0861 (cetak); e-ISSN 2621 - 8712 (online)

website : http://spektrum.stikosa-aws.ac.id 